\title{
東洋医学とその分子生命医科学（その 7)
}

Oriental Medicine and its Molecular Life Science Medicine (Part-7)

\section{初期医学相談研究所}

兵庫県高島 基 史 M. D. . Ph. D.

\section{気・血・水論や三陰三陽五行相生・相剋論の古代生命学説は分 子 DNA 中に存在しており、それに従った治療方針がすへてての 良質遺伝子をつくっている。}

はじめに

東洋医学とその分子生命医科学については、 その 1 を米国のアルゴンネ国立分子生物研究 所、その 2 を韓国の第 5 回国際東洋医学会、そ の 3 を宮崎の第 40 回日本良導絡医学会並びに 国際メディカルアキュパンクチャー・漢方薬学 会、その 4 を京都の日本東洋医学関西支部例 会、その 5 を台北の国立清華大学、その 6 を台 北の中国医薬学院で発表した。近畿大学の有地 博士は薬草治療による病血証の血液成分変化や HLA の遺伝子を文献(1)のように述べている。 筑波大学の田杵博士と東京医科歯科大学の小山 博士らも当帰苟薬散による DNA 複製や脳内二 コチンアセチルコリンレセプターに対する作用 などを文献(2)と(3)のように述べている。ヴェー ダ以前医学の気・血・水や五大論から進化して きた三陰三陽五行・相生相剋論とそれらの存在 は遺伝子レベルでどのような働きがあるかにつ いて科学証明を述べてみよう。

私は遺伝子の専門家ではない。しかしすべて のバイオハイテクの技術を利用して古代バイオ 学説（生命学説=bio-hypothesis）をDNAレ ベルでみることにする。

材料と方法

(1)白血球 1 個中の二重らせん DNA 一本の紐 に存在しているオペロンの陰と陽のしくみを見 るため、23 万倍以上の電子顕微鏡コンピュー ターグラフィックスの画像標本で放射性同位元 素 ${ }^{3} \mathrm{H}$ ・thymidine をリンパ球培養液に添加
しながら 2 時間後に取り出して電子顕微鏡用標 本をつくる。 RNA ポリメラーゼ（RNA polymerase）の玉を見つけるまで 50 万個から 1 億 個以上の白血球が見られた。また、白血球中の 分子 DNA の太さ 20 オングストロームと長さ $170 \mathrm{~cm}$ の 23 万倍の電子顕微鏡写真の撮影がで きた。この白血球 DNA の紐をCT Scan のよ うに輪切りにして全分子 DNA 構造 3 次元コン ピューターグラフィックスの画像をダイナピッ クス $\mathrm{V} /$ バージョンアップと IBM 方式プログ ランムでDNAのアニメーション（分子構造） をつくれば、論文(4)のように五行の相生還状と 似ている 5 つの山のような DNA 外部や中心部 が見られた。

(2)気・血・水論中の活血化瘀め治療方針の存 在を証明するため、和漢医薬の五苓散、小柴胡 湯、大柴胡湯、又は当帰苟薬散などの経口投与 で血液成分変化、ANP 増加、c. AMP 変化、 DNA 合成、Na や排尿の状況を見るため論文 (4)、(5)、(6)、(7)のとおり行った。

(3)五苓散による心房筋細胞中からの強力ペプ チド atrial natriuretic factor $(\mathrm{ANF}=\mathrm{ANP})$ の作用や遺伝子構造を見るため、字験動物又は 慢性の肝・腎疾患などに文献(8)と(10)のとおり治 療を行った。

(4)経絡的電気針治療を文献(4)、(6)、と(9)の之 おり正しく行ってみると、血中 ANF の増加が $\mathrm{Na}$ や水分の排泄ができた。

(5)当帰苓薬散、大黄、電気針治療を文献(14)の とおり行ってみると 4 ・5 後に排卵があり 
妊娠によって子供ができた。

(6)文献(2)の DNA の複製や文献(14)の DNA の 合成などの結果から当帰苟薬散による DNA の 複製の画像を作る。

(7)当帰苟薬散による DNA の合成・複製は非 常に正確に行われていることが 3 次元コン ピューターグラフィックスの画像で証明した。 この DNA の複製モデルによって二重らせん分 子DNA 鎖が作られた。

\section{結 果}

(1)分子 DNA の外部（5つの山のような構 造）が五行の環状と似ているようすと中心部の 基礎の電子顕微鏡コンピューターグラフィック スの 3 次元断面映像は文献(4)のとおりで、白血 球 1 個のオペロンの陰と陽のしくみは文献(6)の ように撮影された。

(2)の治療による血液成分変化、ANP 増加、c. AMP 変化、DNA 合成、 $\mathrm{Na}$ や水分の排泄など の結果も文献(10)のとおりである。

(3)の治療によって ANP の増加やその遺伝子 構造についても文献(7)と(8)が示す。

(4)の治療による ANP 変化を文献(6)が示して いる。

(5)の治療による排卵や妊娠について血中遺伝 子とホルモン成分变化又は $\mathrm{BBT}$ 测定変化など の状況を文献(14)が示している。

(6)当㷌苟薬散による DNA の合成・複製はま ことに正確に行われていることは 3 次元コン ピューターグラフィックスの画像処理で証明さ れている。

(7)当㷌苟薬散による DNA の複製モデルから 二重らせん分子 DNA 鎖が作られた。

\section{まとめ}

古代バイオ学説の三陰三陽五行は分子 DNA の中に存在していることが電子顕微鏡コン ピューターグラフィックスの3 次元画像処理で 撮られた。東洋医学の陰と陽は命をつくる分子 DNA のオペロンの陰と陽であった。今まで理 解しにくかった陰陽を現代の優れたバイオハイ テクの技術、高電圧電子顕微鏡、高性能 ${ }^{3} \mathrm{H}$ ・ thymidine（トリチゥム・チミジン）分子なよ゙
の技術で命の陰と陽のしくみが見られた。その 命の中に存在しているオペロンの陰と陽に従っ て治療を行ってみると非常に効果的であった。 五苓散のような利水剤は分子 DNA の中にオぺ ロンを開く作用又は心房筋細胞中の ANP 顆粒 数の増加作用をむつ。しかし人体の正常な時に はANP を血中へ放出してくれない。それは五 苓散の調節作用と中間的な働きを証明してい る。当帰芶薬散のような利水消腫・活血補血剂 は ANPやc. AMP を増加させ DNA 合成・複 製などの作用をむつ。脳と下垂体内の $\mathrm{Na}$ や水 分の排泄をよくするために働く。それで、脳神 経の伝達物質の流れに及ぼす影響が脸内二コチ ンアセチルコリンやサイトゾルエストゲンレセ プターを増加させる作用で排卯と妊娠が可能に なった。当帰药薬散による DNA の複製がまこ とに正確に行われていることが 3 次元コン ピューターグラフィックスの画像が証明でき た。この DNA の複製モデルから二重らせん分 子 DNA 鎖が作られた。この二重らせんは型板 のような機能をもち、新しい DNA 鎤を合成 し、正しく合成された DNA 鎖ができあがっ た。このようなモデルによって白血球 1 個の中 に複製中の環状 DNA を見ることができた。正 しく行った経絡的電気針治療は選んだ経穴 (ツ ボ）によって血中 ANP の増加が見られた。電 気低周波刺激は細胞内 $\mathrm{Ca}$ の増加と遺伝子導入 作用をむつ。それによる c. AMP 変化、DNA 合 成・複製ができた。慢性の肝・腎疾患も分子 DNA 合成・複製によって改善された。

すべての東洋医学のバイオ学説の気血水、三 陰三陽五行・相生相剋論がすでに述べたように 命の分子 DNA の世界の中で存在していること をバイオ八イテク、薬草又は電気針などの治療 技術が証明してくれた。東洋医学のバイオ学説 は遺伝子にも通じるわけである。

\section{文献 (References)}

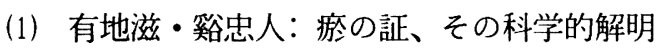
と現代医学への応用、医学と薬学、9(1)、 313-322、1983。

(2) 臼杵悊: 当帰苟薬散の DNA replication に 及ぼす影響について、JAMA（日本語版）、 
38-39、1988 年 4 月号。

（3）小山嵩夫：脳内ニコチンアセチルコリンレ セプターに対する当帰苟薬散の作用、 JAMA（日本語板）、22-23、1988 年 4 月号。

（4）高島基史：五行論、和漢薬、日本的電気針 治療について c. AMP 変化や DNA 合成、 日本良導絡学会誌、32、19（77）-24（82）、 1987。

（5）高島基史：和漢薬の五苓散と和針療法は五 行法則論に従って血中 ANF 量又は心房筋 細胞中 ANF 顆粒数などの調節作用で働い ている、日本良導絡学会誌、32、19（77） -24(82)、1987。

（6）高島基史：五行論、五苓散、電気針などの 話（第 38 回日本東洋医学会発表）、日本良 導絡学会誌、32、11 (95) - 16 (100)、1987。

（7）高島基史：活血化瘀に対する心房筋細胞中 からの強力ペプチド atrial natiuretic factor の作用（その 1 ）、和漢医薬学会誌、 4、438-439、1987。

（8）高島基史：活血化瘀に対する心房筋細胞中 からの強力ペプチド atrial natriuretic factor の作用（その 2 ）、特に五苓散と電 気針による血中 ANF の増加が血液成分中 のレニン・アンジオテンシン系又はアルド ステロン系に与える影響、日本良導絡学会 誌、32、6（212）-11（217）、1987。

（9）高島基史：五行論、経絡、良導絡、電気針、 漢方薬などの話、第 39 回日本良導絡自律 神経学会総会並び学術大会、プログラム並 びに抄録、p.14-16、函館、昭和 62 年 6 月 28 日。

(10) Motofumi Takashima : Lectures on activating blood stagnation、ANF、Goreisan (五苓散)、Shosaikoto (小柴胡湯)、 Daisaikoto（大柴胡湯）、Electrical acupunctures（電気針治療）-Part (3)、 Japan. J. Ryodoraku Medicine、33、 5 (87) -14 (96)、1988。

(11) Motofumi Takashima : Existing nature of activating blood stagnation caused by liver - kidney diseases 、 and their therapeutic principles 、Japan . J . Ryodoraku Medicine 、33、13 (125) - 16 (128)、1988。

(12) Motofumi Takashima : Lectures on Oriental Medicine and its Molecular Biology-Part(1)、Japan . J . Ryodoraku Medicine 、33、13 (151)-21 (159)、1988。

(13) 高島基史：東洋医学とその分子生命医科学 （その 2 )、日本良導絡医学、33、1（213） - 11 (223)、1988。

(14) Motofumi Takashima : The promoting effects of Tokishakuyakusan（当帰苟薬 散)、Daio (大 黄)、Electrical acupunctures（電気針治療）for ovulation (排卵) and pregnancy（妊張）、Japan . J . Ryodoraku Medicine 、 publication for March、34、23 (83) - 31 (91)、1989。 